ARTIKEL PENELITIAN

\title{
Determinan Kejadian Stunting Pada Balita Usia 24-59 Bulan di Wilayah Kerja Puskesmas Silayang Kabupaten Pasaman
}

\author{
*Resty Noflidaputri ${ }^{1)}$, Febriyeni ${ }^{2)}$ \\ Program Studi DIV-Kebidanan, Fakultas Kesehatan, Universitas Fort De Kock \\ Corresponden author: restynoflida@fdk.ac.id
}

Received : July 27, 2020

Accepted : September 23, 2020

Published: September 30, 2020

DOI: https://doi.org/10.37012/jik.v12i2.233

\begin{abstract}
ABSTRAK
Di Indonesia kejadian stunting dianggap kronis selain itu Negara Indonesia menempati peringkat ke 5 dunia. Prevalensi balita stunting tahun 2005-2017 adalah 36,4\%. Di Kabupaten Pasaman tercatat prevalensi status gizi balita stunting berdasarkan TB/U sebesar 26,88\% merupakan kasus kedua tertinggi di Sumatera Barat tahun 2018. Tujuan penelitian untuk mengetahui determinan kejadian stunting pada balita usia $24-$ 59 bulan. Jenis penelitian ini deskriptif analitik dengan pendekatan case control. Populasi kasus pada penelitian ini sebanyak 519 orang dengan sampel 33 orang ibu balita untuk kasus dan 33 orang ibu balita untuk kontrol. Pengambilan sampel menggunakan teknik accidental sampling. Data dianalisa secara univariat dan bivariat menggunakan uji Chi- square. Hasil analisis univariat 66,7\% tidak BBLR, 86,4\% makan dengan beragam makanan, 63,2\% penghindar makanan, 50\% memiliki lingkungan tidak sehat. Analisis bivariat diketahui hubungan stunting dengan BBLR ( $\mathrm{p}$ value $=0,019)$, keragaman makanan ( $\mathrm{p}$ value $=0,031)$, perilaku makan balita $(\mathrm{p}$ value $=0,001)$ dan sanitasi lingkungan ( $\mathrm{p}$ value $=0,003)$. Dapat disimpulkan bahwa terdapat hubungan BBLR, keragaman makanan, perilaku makan balita dan sanitasi lingkungan dengan stunting. Dari semua variabel yang paling mempengaruhi adalah perilaku makan balita. Diharapkan ibu balita dapat mengetahui cara mengatasi balita yang memiliki perilaku penghindar makanan.
\end{abstract}

Kata Kunci: BBLR, Keragaman Makanan, Perilaku Makan Balita, Sanitasi Lingkungan, Stunting.

\section{ABSTRACT}

In Indonesia, the incidence of stunting is considered chronic in addition to that Indonesia is ranked 5th in the world. The prevalence of children under five with stunting in 2005-2017 is 36.4\%. In Pasaman Regency, the prevalence of stunting nutritional status based on TB / U was $26.88 \%$ which was the second highest case in West Sumatra in 2018. The aim of this study was to determine the determinants of stunting incidence in children aged 24 - 59 months. This type of research is descriptive analytic with a case control approach. The population of cases in this study were 519 people with a sample of 33 mothers of children under five for cases and 33 mothers of children under five for controls. Sampling using accidental sampling technique. Data were analyzed univariately and bivariately using the Chi-square test. The results of univariate analysis were $66.7 \%$ were not LBW, $86.4 \%$ ate a variety of foods, $63.2 \%$ were food avoidants, $50 \%$ had an unhealthy environment. The bivariate analysis found that the relationship between stunting and LBW ( $\mathrm{p}$ value $=0.019)$, food diversity $(\mathrm{p}$ value $=0.031)$, toddler eating behavior $(\mathrm{p}$ value $=0.001)$ and environmental sanitation ( $\mathrm{p}$ value $=0.003$ ). It can be concluded that there is a correlation between LBW, food diversity, toddler eating behavior and environmental sanitation with stunting. Of all the variables that most influence is the toddler's eating behavior. It is hoped that mothers of toddlers can find out how to deal with toddlers who have food avoidance behavior.

Keywords: LBW, Food Diversity, Toddler Behavior, Environmental Sanitation, Stunting. 


\section{PENDAHULUAN}

UNICEF menunjukkan hampir sepertiga anak-anak di bawah usia lima tahun di negara-negara berkembang memiliki tubuh pendek. Menurut laporan The Lancet's bahwa prevalensi balita stunting diseluruh dunia mencapai 28,5\% dan pada negara berkembang sebesar 31,2\%. Asia mempunyai prevalensi sebesar 30,6\% (Rahmad, dkk. 2016). Childhood stunting atau tubuh pendek pada masa anak merupakan akibat kekurangan gizi kronis atau kegagalan pertumbuhan di masa lalu dan digunakan sebagai indikator jangka panjang untuk gizi kurang pada anak (Kemenkes RI, 2016).

Menurut World Health Organization (WHO) masalah kesehatan masyarakat dapat dianggap kronis bila prevalensi stunting lebih dari 20 persen. Artinya, secara nasional masalah stunting di Indonesia tergolong kronis. Dalam upaya mewujudkan target Suistainable Development Goals (SDGs) tahun 2030 yaitu mengakhiri segala bentuk malnutrisi, termasuk mencapai target internasional 2025 dengan menurunkan stunting dan wasting pada balita dan mengatasi kebutuhan gizi remaja perempuan, wanita hamil dan menyusui, serta lansia (Ermalena, 2018). Negara Indonesia jika dibandingkan dengan negara lain masuk dalam grup yang mempunyai prevalensi cukup tinggi yaitu 30\%-39\%. Negara Indonesia menempati peringkat ke 5 dunia (Trihono, dkk. 2015). Menurut data Riskesdas tahun 2013 balita stunting berdasarkan TB/U sebanyak 37,2\% (9 juta) sedangkan menurut Sirkesnas tahun 2016 sebanyak 33,6\%. Sedangkan Riskesdas 2018 mencatat prevalensi stunting nasional mencapai 30,8\% terdiri dari 11,5\% sangat pendek dan 19,3 pendek (Kemenkes RI, 2018)

Masalah stunting di 14 provinsi di Indonesia tergolong kategori berat, dan sebanyak 15 provinsi lainnya tergolong kategori serius. Tercatat 18 provinsi yang angka prevalensinya di atas prevalensi nasional. Provinsi Sumatera Barat yang berada di urutan 22 setelah urutan provinsi lainnya dengan prevalensi sedang (Riskesdas, 2018).

Di Kabupaten Pasaman, tercatat prevalensi status gizi balita stunting berdasarkan TB/U (Tinggi Badan menurut Umur) sebesar $26,88 \%$ terdiri dari sangat pendek dan pendek masing-masing adalah 9,05\% dan 17,83\% yang merupakan kasus kedua tertinggi di Sumatera Barat tahun 2018 setelah Kabupaten Pasaman Barat. Balita usia 24-59 bulan termasuk dalam golongan masyarakat kelompok rentan gizi (kelompok masyarakat yang paling mudah menderita kelainan gizi), sedangkan pada saat itu mereka sedang mengalami proses pertumbuhan yang relatif pesat (Ratih, 2014). 
Kecamatan Mapat Tunggul Selatan tergolong dalam zona risiko sangat tinggi untuk tingkat risiko sanitasi. Hal ini bertalian dengan risiko tinggi terhadap status kesehatan masyarakat. Risiko balita stunting dengan sanitasi lingkungan tempat tinggal yang kurang baik, lebih tinggi dibandingkan dengan balita yang tinggal di lingkungan dengan sanitasi yang baik (Profil Dinas Kesehatan Kabupaten Pasaman, 2018).

Dibandingkan dengan puskesmas-puskesmas lainnya di Kabupaten Pasaman, Puskesmas Silayang merupakan puskesmas yang memiliki peringkat ke empat dari 16 puskesmas lainnya yang paling berisiko terhadap masalah gizi. Menurut Profil Kesehatan Kabupaten Pasaman Tahun 2018, kasus BBLR pada tahun 2018 meningkat menjadi 4,59\% dibandingkan dengan tahun 2017 sebesar 2,67\% dari total kelahiran hidup, jumlah tersebut masih terbilang tinggi, dimana BBLR (Berat Badan Lahir Rendah) di Puskesmas Silayang sebanyak 4 kasus (10,3\%) (Dinkes Provinsi Pasaman, 2018).

Berdasarkan laporan tahunan puskesmas Silayang tahun 2018 kasus stunting sebesar 34,45\%, terbagi pendek sebesar 25,32\% dan sangat pendek sebesar 9,13\%. Masalah stunting Puskesmas Silayang di nilai berat karena prevalensi stunting berada pada rentang 30-39\%. Berdasarkan survei awal yang dilakukan dengan 10 orang responden ibu balita usia $24-59$ bulan di wilayah kerja Puskesmas Silayang diketahui penyebab stunting yang menarik untuk diteliti diantaranya Berat Badan Lahir Rendah (BBLR), perilaku makan balita, sanitasi lingkungan, keragaman makanan, status ekonomi keluarga, jumlah anggota keluarga dan pemanfaatan pelayanan kesehatan.

\section{METODE}

Penelitian ini tentang determinan kejadian stunting pada balita usia 24 - 59 bulan di wilayah kerja Puskesmas Silayang Kabupaten Pasaman tahun 2019. Tujuan penelitian ini untuk melihat hubungan antara variabel independent (Berat Badan Lahir Rendah, Keragaman Makanan, Perilaku Makan Balita dan Sanitasi Lingkungan) dan dependent (Stunting). Jenis penelitian ini Deskriftif Analitik dengan metode pendekatan Case Control. Penelitian ini dilakukan di wilayah kerja Puskesmas Silayang Kabupaten Pasaman pada Agustus 2019. Populasi kasus pada penelitian ini adalah balita usia 24 - 59 bulan yang mengalami kejadian stunting di wilayah kerja Puskesmas Silayang pada bulan Desember yaitu sebanyak 151 balita dan populasi kontrol pada penelitian ini adalah balita yang tidak mengalami kejadian stunting di wilayah Puskesmas Silayang pada bulan Desember yaitu 368 balita. Sampel yang digunakan sebanyak 33 orang untuk kasus dan 33 orang untuk kontrol dengan ibu balita 
sebagai responden dengan pengambilan sampel Accidental Purposive Sampling. Pengumpulan data dilakukan dengan menggunakan kuesioner, kemudian dianalisa secara univariat dan bivariate dengan uji statistik Chi-Square. Dalam penelitian ini penulis membatasi ruang lingkup penelitian yang meneliti tentang determinan kejadian stunting pada balita usia $24-59$ bulan.

\section{HASIL DAN PEMBAHASAN}

\section{Hasil}

\section{Analisis Univariat}

Tabel 1

Distribusi Frekuensi di Wilayah Kerja

Puskesmas Silayang Kabupaten Pasaman

\begin{tabular}{clcc}
\hline No & \multicolumn{1}{c}{ Variabel } & Frekuensi $(\boldsymbol{f})$ & Persentase (\%) \\
\hline 1 & BBLR & & \\
& BBLR & 22 & 33,3 \\
& Tidak BBLR & 44 & 66,7 \\
\hline 2 & Keragaman Makanan & & \\
& Tidak Beragam & 9 & 13,6 \\
& Beragam & 57 & 86,4 \\
\hline 3 & Perilaku Makan Balita & 38 & \\
& Penghindar Makanan & 28 & 63,2 \\
& Penyuka Makanan & & 36,8 \\
\hline 4 & Sanitasi Lingkungan & 33 & 50 \\
& Lingkungan Tidak Sehat & 33 & 50 \\
& Lingkungan Sehat & & \\
\hline 5 & Stunting & 33 & 50 \\
& Stunting & 33 & 50 \\
\hline
\end{tabular}

Berdasarkan tabel 1 dapat dijelaskan bahwa dari 66 orang responden, sebanyak 22 orang responden atau 33,3\% yang mengalami BBLR dan sebanyak 44 orang responden atau $66,7 \%$ yang tidak BBLR. Keragaman Makanan pada 9 orang responden atau 13,6\% yang tidak makan beragam makanan dan sebanyak 57 orang responden atau 86,4\% yang makan dengan beragam makanan. Perilaku Makan Balita pada 38 orang responden atau 63,2\% yang penghindar makanan dan sebanyak 28 orang responden atau $36,8 \%$ yang penyuka makanan. Pada Sanitasi Lingkungan dan Stunting sebagaian responden memiliki lingkungan tidak sehat dan sebagian lagi memiliki lingkungan sehat yaitu sebanyak 33 orang responden atau $50 \%$. 


\section{Analisis Bivariat}

Tabel 2

Analisis Bivariat

\begin{tabular}{|c|c|c|c|c|c|c|c|}
\hline \multirow{3}{*}{ Variabel } & \multicolumn{4}{|c|}{ Stunting } & \multirow{3}{*}{$\begin{array}{c}\text { Jumlah } \\
(\mathbf{N})\end{array}$} & \multirow{3}{*}{$\begin{array}{c}p \\
\text { value }\end{array}$} & \multirow{3}{*}{$\mathbf{R R}$} \\
\hline & \multicolumn{2}{|c|}{ Stunting } & \multicolumn{2}{|c|}{$\begin{array}{c}\text { Tidak } \\
\text { Stunting }\end{array}$} & & & \\
\hline & $n$ & $\%$ & $n$ & $\%$ & & & \\
\hline \multicolumn{7}{|l|}{$\overline{\text { BBLR }}$} & \multirow{3}{*}{$\begin{array}{c}1,882(1,198- \\
2,957)\end{array}$} \\
\hline BBLR & 16 & 48,5 & 6 & 18,2 & 22 & \multirow[t]{2}{*}{0,019} & \\
\hline Tidak BBLR & 17 & 51,5 & 27 & 81,8 & 44 & & \\
\hline \multicolumn{7}{|l|}{ Keragaman Makanan } & \multirow{3}{*}{$\begin{array}{c}2,027(1,395- \\
2,945)\end{array}$} \\
\hline Tidak Beragam & 8 & 24,2 & 1 & 3,0 & 9 & \multirow[t]{2}{*}{0,031} & \\
\hline Beragam & 25 & 75,8 & 32 & 97,0 & 57 & & \\
\hline \multicolumn{7}{|l|}{ Perilaku Makan Balita } & \multirow{3}{*}{$\begin{array}{c}2,737(1,391- \\
5,386)\end{array}$} \\
\hline Penghindar Makanan & 26 & 78,8 & 12 & 36,4 & 38 & \multirow[t]{2}{*}{0,001} & \\
\hline Penyuka Makanan & 7 & 21,2 & 21 & 63,6 & 28 & & \\
\hline \multicolumn{7}{|l|}{ Sanitasi Lingkungan } & \multirow{3}{*}{$\begin{array}{c}2,300(1,308- \\
4,044)\end{array}$} \\
\hline Lingkungan Tidak Sehat & 23 & 69,7 & 10 & 30,3 & 33 & \multirow[t]{2}{*}{0,003} & \\
\hline Lingkungan Sehat & 10 & 30,3 & 23 & 69,7 & 33 & & \\
\hline
\end{tabular}

Berdasarkan tabel 2 dapat dijelaskan bahwa dari hasil analisis hubungan BBLR, Keragaman Makanan, Perilaku Makan Balita, dan Sanitasi Lingkungan menunjukan bahwa ada hubungan dengan kejadian Stunting. Hasil uji Chi-square terhadap semua variabel dengan stunting di dapat nilai p value $<0,05$.

\section{PEMBAHASAN}

Berdasarkan Hasil penelitian menunjukan bahwa dari 33 orang responden stunting yang BBLR sebanyak 16 orang responden atau $48,5 \%$, sedangkan dari 33 orang responden tidak stunting yang BBLR sebanyak 6 orang responden atau 18,2\%. Hasil uji Chi-square terhadap BBLR dengan stunting di dapat nilai p value $=0,019(\mathrm{p}<0,05)$, Analisis keeratan hubungan dua variabel didapatkan nilai Relative Risk $(\mathrm{RR})=1,882$ artinya responden BBLR memiliki peluang untuk stunting sebanyak 2 kali lebih besar dibandingkan responden tidak BBLR.

Berat badan bayi yang lahir dipengaruhi oleh konsumsi gizi selama kehamilan. Bayi yang lahir dengan berat badan lahir rendah dapat mempengaruhi hambatan pertumbuhan dan perkembangan balita. Sehingga balita akan mudah untuk terserang peyakit dan infeksi salah satunya seperti stunting. Agar hal tersebut tidak terjadi, maka diperlukannya promosi kesehatan berupa edukasi tentang konsumsi gizi selama kehamilan agar bayi yang dilahir dengan berat badan normal. Sehingga kemungkin anak akan mengalami stunting akan sedikit karena kecukupan gizi yang tercukup sejak didalam kandungan dapat membantu kemajuan pertumbuhan dan perkembangan balita yang baik. 
Bayi berat lahir rendah (BBLR) adalah bayi dengan berat badan lahir kurang dari 2500 gram tanpa memandang usia gestasi. Berat saat lahiradalah berat bayi yang ditimbang dalam 1 jam setelah lahir (Manuaba et al, 2007). Acuan lain dalam pengukuran BBLR juga terdapat pada Pedoman Pemantauan Wilayah Setempat (PWS) gizi. Dalam pedoman tersebut bayi berat lahir rendah (BBLR) adalah bayi yang lahir dengan berat kurang dari 2500 gram diukur pada saat lahir atau sampai hari ke tujuh setelah lahir (Putri, 2012).

Penelitian ini tidak sejalan dengan penelitian Devilya (2015) tentang faktor yang berhubungan dengan kejadian stunting pada balita yang menunjukan bahwa tidak ada hubungan antara berat badan lahir dengan stunting, nilai $\mathrm{p}$ value $=1,000$. Namun penelitian ini sejalan dengan penelitian Ani, dkk (2016) yang menjelaskan bahwa adanya hubungan antara berat badan lahir dengan stunting, nilai p value $=0,00$.

Berdasarkan hasil penelitian menunjukan bahwa dari 33 orang responden stunting yang makan tidak beragam sebanyak 8 orang responden atau 24,2\%, sedangkan dari 33 orang responden tidak stunting yang makan tidak beragam sebanyak 1 orang responden atau 3\%. Hasil uji Chi-square terhadap Keragaman Makanan dengan stunting di dapat nilai $\mathrm{p}$ value $=0,031$ ( $\mathrm{p}<$ 0,05). Analisis keeratan hubungan dua variabel didapatkan nilai Relative Risk $(\mathrm{RR})=2,027$ artinya responden yang makan tidak beragam memiliki peluang untuk stunting sebanyak 2 kali lebih besar dibandingkan responden yang makan dengan beragam.

Kualitas atau mutu gizi dan kelengkapan zat gizi dipengaruhi oleh keragaman jenis pangan yang dikonsumsi. Semakin beragam jenis makanan yang dikonsumsi semakin mudah untuk memenuhi kebutuhan gizi, semakin mudah tubuh memperoleh berbagai zat lainnya yang bermanfaat bagi kesehatan oleh karena itu aneka ragam makanan merupakan salah satu anjuran penting dalam mewujutkan gizi seimbang (Kemenkes RI, 2015). Keanekaragaman pangan/makanan adalah aneka ragam kelompok pangan yang terdiri dari makanan pokok, lauk pauk, ssayuran dan buah - buahan dan air serta beranekaragam dalam setiap kelompok pangan.

Penelitian ini sejalan dengan penelitian Atikah, dkk (2015) tentang keragaman pangan, pola asuh makan dan kejadian stunting pada balita usia 24 - 59 bulan yang menunjukan adanya hubungan antara keragaman pangan dengan stunting yaitu nilai p value $=0,024$.

Berdasarkan hasil penelitian menunjukan bahwa dari 33 orang responden stunting yang penghindar makanan sebanyak 26 orang responden atau 78,8\%, sedangkan dari 33 orang responden tidak stunting yang penghindar makanan sebanyak 12 orang responden atau $36,4 \%$. 
Hasil uji Chi-square terhadap perilaku makan balita dengan stunting di dapat nilai p value = $0,001$ ( $\mathrm{p}<0,05)$. Analisis keeratan hubungan dua variabel didapatkan nilai Relative Risk (RR) $=2,737$ artinya responden yang penghindar makanan memiliki peluang untuk stunting sebanyak 3 kali lebih besar dibandingkan responden yang penyuka makanan.

Perilaku makan merupakan perilaku yang sudah dialami sejak masih kecil meliputi keputusan mengenai kapan, apa, bagaimana, berapa jumlahnya, dimana, dan dengan siapa akan makan. Seringkali dalam membuat keputusan untuk makan cukup mempertimbangkan hal-hal seperti dimana akan makan dan apa yang akan dimakan (Fassah dan Retnowati, 2014). Perilaku makan anak adalah perilaku atau cara yang ditempuh anak untuk memilih makanan berdasarkan ketertarikan terhadap makanan, keinginan untuk makan, keinginan untuk minum, perasaan saat makan, kecepatan saat makan, dan pemilihan jenis makanan baru (Wardle, dkk. 2001).

Penelitian ini sejalan dengan penelitian Dewi, dkk (2017) tentang perbedaan perilaku makan dan pola asuh pembeerian makan antara balita gemuk dan balita non gemuk di Kota Semarang yang menunjukan adanya hubungan antara perilaku makan dengan balita gemuk dan non gemuk, nilai p value $=0,007$. Sedangkan pada penelitian Diaz, dkk (2017) tentang fenomena perilaku makan toddler dan hubungannya dengan perlaku pemberian mkan orang tua menunjukan adanya hubungan antara perilaku makan anak denga perlaku orang tua dalam pemberian makan pada anak yaitu nilai p value $=0,05$.

Berdasarkan hasil penelitian menunjukan bahwa dari 33 orang responden stunting yang sanitasi lingkungan tidak sehat sebanyak 23 orang responden atau $69,7 \%$, sedangkan dari 33 orang responden tidak stunting yang sanitasi lingkungan tidak sehat sebanyak 10 orang responden atau 30,3\%. Hasil uji Chi-square terhadap sanitasi lingkungan dengan stunting di dapat nilai $\mathrm{p}$ value $=0,003(\mathrm{p}<0,05)$, Analisis keeratan hubungan dua variabel didapatkan nilai Relative Risk $(\mathrm{RR})=2,300$ artinya responden yang sanitasi lingkungan tidak sehat memiliki peluang untuk stunting sebanyak 2 kali lebih besar dibandingkan responden yang sanitasi lingkungan sehat.

Faktor Lingkungan sangat menentukan tercapainya potensigenetik yang optimal. Apabila kondisi lingkungan kurang mendukung atau jelek, maka potensi genetik yang optimal tidak akan tercapai. Lingkungan ini meliputi lingkungan bio, psiko, dan psikososial yang akan mempengaruhi setiap individu mulai mulai masa konsepsi sampai akhir hayatnya. Secara garis besar, faktor lingkungan dapat dibagi menjadi dua yaitu faktor pranatal dan lingkungan pasca natal. Faktor lingkungan pranatal adalah faktor lingkungan yang mempengaruhi anak pada 
waktu masih dalam kandungan. Faktor pasca natal adalah faktor lingkungan yang mempengaruhi pertumbuhan anak setelah lahir (Supariasa, 2012).

Penelitian ini sejalan dengan Nadiyah, dkk (2014) tentang faktor risiko stuting pada anak usia 0 - 23 bulan di Provinsi Bali Jawa Barat san Nusa Tenggar Timur yang menunjukan adanya hubbungan antara sanitasi lingkungan dengan resiko stunting, nilai $\mathrm{p}$ value $=0,003$. Sedangkan pada penelitian Wina (2014) tentang sanitasi lingkungan yang tidak baik mempengaruhi status gizi pada balita menunjukan tidak adanya hubungan sanitasi lingkungan dengan status gizi balita dengan nilai $\mathrm{p}$ value $=0,111$.

\section{KESIMPULAN}

Berdasarkan hasil penelitian dan pembahasan tentang Determinan Kejadian Stunting Pada Balita Usia 24-59 Bulan di Wilayah Kerja Puskesmas Silayang Kabupaten Pasaman dapat disimpulkan bahwa BBLR, Keragaman Makanan, Perilaku Makan Balita dan Sanitasi Lingkungan terdapat hubungan yang signifikan. Masyarakat diharapkan memperhatikan pola asuh pertumbuhan dan perkembangan anak balitanya untuk lebih mengetahui faktor resiko yang mempengaruhi stunting. Dan Petugas diharapkan melakukan promosi kesehatan tentang stunting pada balita, sehingga ibu mempunyai pengetahuan yang luas dan mempunyai motivasi yang tinggi dalam menghindari kejadian stunting pada balita.

\section{UCAPAN TERIMA KASIH}

Terimakasih pada segenap jajaran Puskesmas Silayang Kabupaten Pasaman atas dukungan dalam penelitian ini, serta responden yang telah ikut berpartisipasi dalam melakukan penelitian ini. Selanjutnya, terima kasih kepada Institusi dan rekan-rekan yang telah memberi saran dan masukan atas penelitian ini dan dapat digunakan untuk penelitian selanjutnya.

\section{REFERENSI}

1. Dewi, Devillya Puspita. 2015. Status Stunting Kaitannya dengan Pemberian ASI Eksklusif pada Baita di Kabupaten Gunung Kidul. Jurnal Medika Respati Vol X nomor 4 Oktober 2015: 60-65

2. Dinas Kesehatan Kabupaten Pasaman. 2018. Profil Kesehatan Kabupaten Pasaman Tahun 2017. Pasaman: Dinas Kesehatan Kabupaten Pasaman

3. Fassah, DR \& Sofia Retnowati. (2014). Hubungan Antara Emotional Distress dengan Perilaku Makan Tidak Sehat pada Mahasiswa Baru. Fakultas Psikologi Universitas Gadjah Mada. 
4. Keputusan Menteri Kesehatan Republik Indonesia No : 1995/Menkes/SK/XII/2010 tentang Standar Antropometri Penilaian Status Gizi Anak. Kementerian Kesehatan Direktorat Jenderal Bina Gizi dan Kesehatan Ibu Dan Anak Direktorat Bina Gizi, Jakarta.

5. Unicef Indonesia, 2013. Ringkasan Kajian Gizi Ibu dan Anak, Oktober 2012. Tersedia www.unicef.org (diakses tanggal 25 Oktober 2018)

6. Wardle J, Guthrie, C.A., Sanderson, S., R. L. Development of Children's Eating Behavior Quesionnaire. J. Child Psychol. Psychiatry42, 963-970 (2001). 